
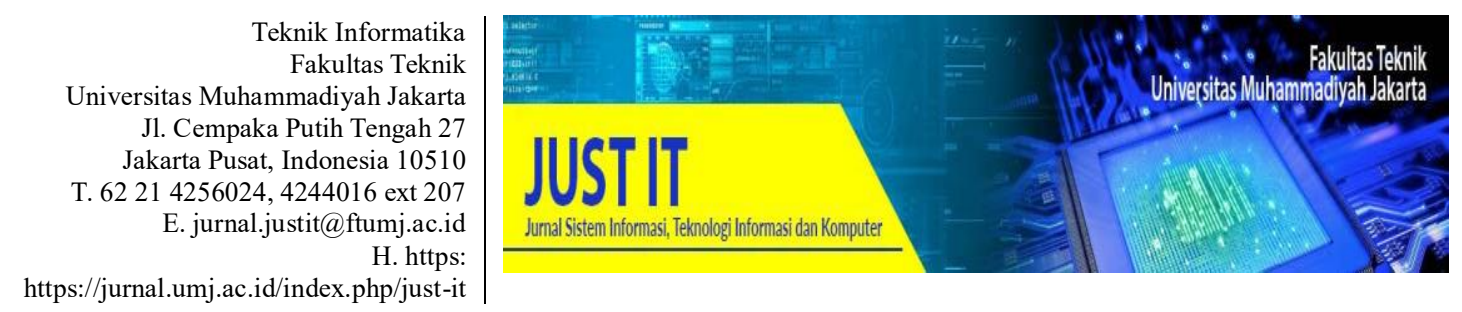

\title{
PENGEMBANGAN TAMPILAN ANTARMUKA APLIKASI SURVEI BERBASIS WEB DENGAN METODE USER CENTERED DESIGN
}

\author{
Dicky Larson Kaligis ${ }^{1}$, Refyul Rey Fatri ${ }^{2}$ \\ Program Studi Sistem Informasi, FTIK, Universitas Bakrie \\ dickylarsonkaligis@gmail.com ${ }^{1}$, refyul.fatri@bakrie.ac.id ${ }^{2}$
}

\begin{abstract}
Abstrak
Survei adalah aktivitas pengumpulan data yang digunakan untuk bahan analisis bagi organisasi. Namun dalam prosesnya seringkali ditemui kesulitan, sehingga dibangunlah aplikasi survei berbasis web yang merupakan media pengumpulan data responden yang lebih mudah digunakan. Penelitian ini membahas bagaimana mengembangkan tampilan antarmuka dengan melibatkan pengguna secara langsung. Metode yang digunakan pada penelitian ini adalah User Centered Design (UCD), yang merupakan metodologi pengembangan sistem berfokus pada peran pengguna dalam proses pengembangan sistem. Pada penelitian ini dibahas pengembangan tampilan antarmuka aplikasi survei berbasis web mulai dari analisis konteks pengguna, analisis kebutuhan pengguna, perancangan desain solusi dan evaluasi desain solusi. Hasil dari penelitian ini menampilkan desain tampilan antarmuka yang dirancang menggunakan metode UCD memiliki nilai usability yang lebih baik dari sebelumnya. Pada aspek efektivitas diperoleh tingkat keberhasilan sebesar $100 \%$. Pada aspek efisiensi diperoleh rata-rata waktu pengerjaan yang lebih baik dari sebelumnya. Pada aspek kepuasan pengguna diperoleh nilai sebesar $85,6 \%$ pengguna merasa puas dengan tampilan antarmuka yang tersedia.
\end{abstract}

Kata Kunci: User Centered Design, usability, tampilan antamuka, aplikasi survei berbasis web

\begin{abstract}
A survey is a data collection activity that uses for analysis needs for the organization. But in the process they meet some difficulties, so a web-based survey application was built for easily collecting respondents' data. This research focuses on how developing user interface by involving users directly. A method that can be focus on user role in the system development is User-Centered Design (UCD). this research will discuss about developing user interface from the context of use, user requirement, developing design solution and evaluating design solution. The result of this research showed that user interface design had a better usability score after using the UCD method. For the effectivity aspect, the result was $100 \%$ users can use the system. For the efficiency aspect, the average time result was increased rather than the first design. For the user satisfaction aspect, the result was $85,6 \%$ users satisfied with the current user interface.
\end{abstract}

Keywords: User Centered Design, usability, user interface, web-based survey application

\section{Pendahuluan}

Survei merupakan aktivitas pengumpulan data yang dapat dimanfaatkan sebagai bahan analisis serta evaluasi bagi suatu perusahaan, organisasi maupun institusi tertentu. Penelitian survei yang dilakukan oleh perusahaan akan menghasilkan gambarangambaran detail mengenai suatu hal yang sedang diteliti baik berupa kejadian relatif, distribusi maupun hubungan antar variabel tertentu. Bagi perusahaan maupun institusi pemerintah yang berfokus pada pelayanan masyarakat tentu perlu melakukan evaluasi mengenai layanan-layanan yang telah dilakukan sebelumnya guna mengidentifikasi masalah-masalah dan memperoleh justifikasi dari kejadian-kejadian yang ada, hal tersebut 
membuat peranan survei sebagai media pengumpulan data menjadi sangat penting dan krusial, mengingat survei dapat dijadikan bahan tolak ukur bagi perusahaan maupun institusi pemerintah untuk memperoleh penilaian dari masyarakat mengenai layananlayanan yang diberikan.

Penggunaan perangkat teknologi yang sudah merambah ke kehidupan sehari-hari membuat berbagai pekerjaan menjadi mudah dan dapat terintegrasi dengan baik, salah satunya ialah pemanfaatan media web sebagai wadah untuk pelaksanaan survei. Melalui pemanfaatan media web maka pelaksanaan survei tidak hanya terbatas pada ruang lingkup tertentu saja, melainkan dapat mencakup seluruh ruang lingkup yang dibutuhkan oleh perusahaan maupun intitusi.

Aplikasi survei berbasis web merupakan website yang berfungsi sebagai media penunjang kebutuhan pengumpulan data survei sehingga berdasarkan data-data tersebut dapat dilakukan analisis mengenai suatu kondisi tertentu.

Pada pengembangan tampilan antarmuka aplikasi survei berbasis web sebelumnya, dilakukan berdasarkan sudut pandang admin yang mengelola data survei saja tanpa melibatkan responden yang menjadi aktor dalam proses pengisian survei tersebut, sehingga dibutuhkan peran dari pengguna (responden) dalam mengembangkan tampilan antarmuka aplikasi survei berbasis web khususnya tampilan yang akan dihadapi oleh masyarakat secara luas. Mengingat sebuah aplikasi akan dapat mudah digunakan oleh pengguna apabila dalam pengembangan aplikasi tersebut pengguna menjadi prioritas utama (Mastery, 2019). Berdasarkan penelitian yang dilakukan oleh AppAgent dapat diketahui bahwa pengguna aplikasi umumnya memakan waktu 7 detik untuk memutuskan apakah akan melanjutkan menggunakan aplikasi tersebut atau tidak (Fodor, 2017).

Berdasarkan permasalahan tersebut maka dibutuhkan metode atau pendekatan User Centered Design (UCD) untuk mengembangkan tampilan antarmuka aplikasi survei berbasis web. Pengembangan aplikasi dilakukan dengan memanfaatkan pendapat pengguna dan pola dari tingkah laku pengguna dalam menggunakan aplikasi. Adapun tujuan dari digunakannya metode UCD ialah untuk memberikan rekomendasi kepada pengembang aplikasi dalam menyelesaikan masalah kemudahan dan ketertarikan pengguna dalam menggunakan aplikasi survei berbasis web. Menurut ISO 9241-210:2010, UCD merupakan pendekatan dalam pengembangan sistem secara interaktif dengan tujuan untuk mengembangkan sistem yang berguna bagi penggunanya. Mengingat metode UCD melibatkan peran pengguna sejak tahap awal pengembangan aplikasi maka aplikasi dapat benar-benar dirancang dan dibangun berdasarkan masukan-masukan mengenai tampilan antarmuka aplikasi survei berbasis web. Adapun hasil akhir dari pengembangan aplikasi ini diharapkan mampu menghasilkan sebuah desain rekomendasi untuk pengembang agar dapat mengembangkan tampilan antarmuka yang memiliki nilai usability dan kepuasan pengguna yang baik. Adapun pendekatan UCD yang digunakan pada pengembangan aplikasi ini ialah kuesioner dan usability testing.

\section{Landasan Teori}

\section{A. Penelitian Terdahulu}

Penelitian yang membahas pendekatan UCD telah banyak dilakukan oleh berbagai pihak. Diantaranya ialah penelitian yang dilakukan oleh Moh. Rendiansah (2017), pada penelitian tersebut dihasilkan rekomendasi desain tampilan antarmuka untuk aplikasi berbasis web Guide Me! yang dikembangkan untuk mempertemukan pemandu wisata dengan pengunjung tempat wisata di Jawa Timur. Adapun penelitian tersebut dilakukan karena aplikasi berbasis web sebelumnya dikembangkan hanya berdasarkan sudut pandang pengembang aplikasi saja tanpa melibatkan peran pengguna dalam mengembangkan tampilan antarmuka, sehingga diperlukan pendekatan UCD agar dalam proses pengembangannya dapat melibatkan pengguna secara langsung.

Adapun penelitian serupa juga dilakukan oleh Intan Sandra (2017), penelitian tersebut menghasilkan sistem e-commerce yang mampu menghasilkan tampilan 
antarmuka serta fungsi yang maksimal didasarkan pada penilaian usability dari sistem e-commerce tersebut. Penelitian tersebut dilakukan mengingat sistem e-commerce sebelumnya dirancang hanya berfokus pada tujuan bisnis, fitur-fitur yang melimpah dan kemampuan software dan hardware yang tersedia saat itu tanpa melibatkan pihak yang akan menggunakan sistem tersebut, sehingga diperlukan metode UCD dalam perancangan sistemnya.

\section{B. Aplikasi Survei Berbasis Web}

Jika dilihat dari definisi mengenai aplikasi berbasis web menurut Rouse (2011), merupakan sistem yang disimpan dalam server dan dikirim melalui jaringan dan dapat diakses melalui tampilan antarmuka pada halaman web oleh pengguna. Sedangkan jika dilihat dari definsi mengenai survei menurut Morissan (2014), survei merupakan metode untuk melakukan analisis dari suatu fenomena tertentu yang memiliki kepentingan tertentu.

Berdasarkan definisi-definisi tersebut dapat disimpulkan bahwa aplikasi survei berbasis web merupakan sistem survei elektronik yang terintegrasi melalui jaringan internet dan ditampilkan melalui tampilan antarmuka sehingga terkumpul suatu data yang dapat dilakukan analisis terhadap fenomena tertentu.

\section{User Centered Design}

User Centered Design (UCD) merupakan pendekatan yang digunakan untuk mengembangkan sistem secara interaktif yang melibatkan pengguna dalam proses pengembangannya. Menurut ISO 9241210:2010, UCD merupakan metode dalam perancangan dan pengembangan sistem yang bertujuan untuk melibatkan pengguna dalam proses pembangunan sistem sehingga mampu menyesuaikan dengan kebutuhan pengguna. Sedangkan menurut Fitria Febriana (2017) UCD merupakan teknik desain tampilan yang mengacu pada kebutuhan dari pengguna tampilan tersebut. Mengingat peran pengguna sangat ditekankan pada tahap proses pengembangan sistem maka nilai kebergunaan (usability) sangat berpengaruh terhadap kepuasan pengguna. Pendekatan UCD juga dapat meningkatkan nilai usability berdasarkan aspek efektivitas, efisiensi dan kepuasan pengguna (ISO 9241-210:2010).

Dalam proses pengembangan aplikasi menggunakan metode UCD, terdapat beberapa tahapan yang dilakukan secara iteratif atau dapat mengulang sesuai dengan kebutuhan. Adapun tahapan-tahapan yang dimaksud ialah sebagai berikut:

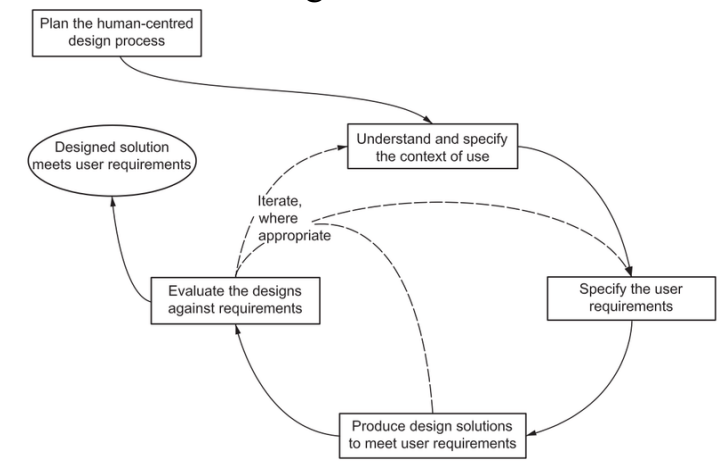

Gambar. 1. Tahapan User Centered Design (ISO 9241210:2010, 2010)

Berikut penjelasan dari tahapantahapan UCD yang ditampilkan pada Gambar 1:

1. Understand and Specify the Context of Use

Tahapan ini melakukan proses identifikasi pengguna dengan berfokus pada kondisikondisi seperti apa yang dapat membuat pengguna menggunakan aplikasi.

2. Specify the User Requirements

Tahapan ini melakukan proses identifikasi kebutuhan pengguna dalam menggunakan aplikasi.

3. Produce Design Solutions to Meet User Requirements

Pada tahapan ini dilakukan proses pembangunan desain tampilan sebagai solusi dari aplikasi yang dibangun.

4. Evaluate the Designs Against Requirements

Tahapan ini melakukan proses evaluasi terhadap desain yang dibangun dengan mengacu pada hasil analisis konteks dan kebutuhan pengguna.

Dalam proses pengumpulan data menggunakan metode UCD juga didukung dengan beberapa pendekatan tertentu yang dapat dipilih sesuai kebutuhan, adapun pendekatan-pendekatan yang dimaksud ialah 
sebagai berikut:

TABEL 1

Pendekatan USER CENTERED DESIGN (SRIPATHI \& SANDRU, 2013)

\begin{tabular}{|l|c|c|c|}
\hline & Analyze & Design & Test \\
\hline Card Sorting & $\checkmark$ & $\checkmark$ & $\checkmark$ \\
\hline $\begin{array}{l}\text { Contextual } \\
\text { Interviews }\end{array}$ & $\checkmark$ & & \\
\hline Focus Groups & $\checkmark$ & $\checkmark$ & \\
\hline $\begin{array}{l}\text { Heuristic } \\
\text { Evaluation }\end{array}$ & $\checkmark$ & & $\checkmark$ \\
\hline $\begin{array}{l}\text { Individual } \\
\text { Interviews }\end{array}$ & $\checkmark$ & $\checkmark$ & $\checkmark$ \\
\hline Parallel Design & & $\checkmark$ & \\
\hline Personas & $\checkmark$ & & \\
\hline Prototyping & & $\checkmark$ & $\checkmark$ \\
\hline Surveys (Online) & $\checkmark$ & $\checkmark$ & $\checkmark$ \\
\hline Task Analysis & $\checkmark$ & & \\
\hline Usability Testing & $\checkmark$ & $\checkmark$ & $\checkmark$ \\
\hline Use Cases & & $\checkmark$ & \\
\hline Writing for the Web & & $\checkmark$ & \\
\hline
\end{tabular}

\section{Usability}

Berdasarkan ISO DIS 9241-11 (2015) usability merupakan tingkatan efektivitas, efisiensi dan kepuasan yang dapat membuat pengguna mampu mencapai tujuannya dalam menggunakan aplikasi. Sedangkan menurut Nielsen (2012) usability merupakan analisis penilaian kualitatif tingkat kemudahan dari penggunaan suatu aplikasi oleh pengguna, sehingga pengguna akan meninggalkan aplikasi jika menemui kesulitan yang tidak dapat ditanganinya. Adapun tujuan dilakukannya usability testing ialah untuk mengidentifikasi apakah aplikasi telah dibangun sesuai dengan kebutuhan pengguna. Selain itu penentuan jumlah evaluator yang dilakukan pada usability testing cukup berjumlah 5 orang saja, hal ini dikarenakan dengan melakukan usability testing kepada 5 evaluator telah mampu memperlihatkan $85 \%$ masalah yang ada pada tampilan antarmuka (Nielsen, 2012).

Menurut ISO 9241-11 (2018) terdapat tiga kriteria dari usability,

a. Efektivitas

Tingkat kelengkapan dari fitur yang tersedia pada aplikasi akan mempengaruhi proses pemenuhan kebutuhan pengguna dalam menggunakan aplikasi.

b. Efisiensi
Tingkat kemudahan dari penggunaan aplikasi akan mempengaruhi ketertarikan pengguna dalam menggunakan aplikasi.

c. Kepuasan

Tingkat efektivitas dan efisiensi dari aplikasi akan mempengaruhi rasa puas pengguna ketika menggunakan aplikasi.

\section{Metodologi Penelitian}

Pada penelitian ini metodologi yang dilakukan ialah melakukan studi guna melengkapi kebutuhan untuk pengembangan aplikasi dengan mengumpulkan data-data dari berbagai sumber dan melakukan wawancara terhadap pihak-pihak terkait.

Pada Gambar 2 berikut dijelaskan alur dari pelaksanaan penelitian ini.

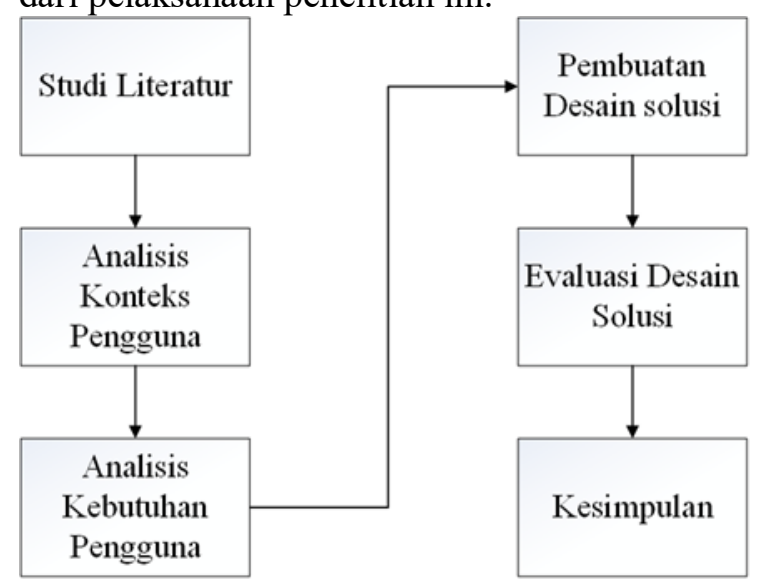

Gambar. 2. Metodologi Penelitian

\section{A. Studi Literatur}

Pada tahapan ini dilakukan analisis dari berbagai referensi untuk dijadikan landasan dalam melakukan penelitian ini. Studi literatur yang dilakukan berfokus pada materi yang membahas hal-hal berikut:

a. Aplikasi Survei Berbasis Web;

b. User Centered Design;

c. Usability Testing.

\section{B. Analisis Konteks Pengguna}

Tahapan analisis kebutuhan pengguna dilakukan pencarian data mengenai kebutuhan dari pengguna serta kendala yang ditemui berdasarkan aspek ergonomi dan usability. Untuk memperoleh data mengenai kebutuhan dan kendala maka dibutuhkan pengambilan data dari pengguna yang terdapat pada hasil analisis konteks pengguna. Hasil akhir dari 
tahapan ini adalah diketahuinya kebutuhan serta kendala dari masing-masing aspek usability untuk selanjutnya digunakan sebagai bahan pertimbangan dalam merancang desain solusi.

\section{Analisis Kebutuhan Pengguna}

Untuk melakukan analisis konteks pengguna diperlukan beberapa data yang berhubungan dengan pengguna, diantaranya ialah karakteristik dan tugas dari pengguna ketika mengakses aplikasi. Adapun hasil akhir dari analisis konteks pengguna ini berupa penjabaran mengenai karakteristik dan tugas yang akan dikerjakan oleh pengguna.

\section{Pembuatan Desain Solusi}

Pembuatan desain solusi dilakukan dengan mengacu pada hasil analisis kebutuhan pengguna dan design guideliness and standards. Adapun design guideliness and standards yang dimaksud ialah menggunakan design guideliness and standards dari Department of Health and Human Services Guidelines (HHS Guidelines). Hasil akhir dari tahapan ini ialah rancangan desain sebagai jawaban dari kebutuhan dan kendala yang dihadapi oleh pengguna.

\section{E. Evaluasi Desain Solusi}

Tahapan ini melakukan evaluasi dari desain solusi yang telah dirancang pada tahapan sebelumnya dalam aspek ergonomi dan usability. Evaluasi dilakukan dengan menggunakan kuesioner terhadap pengguna yang menjadi evaluator dari aplikasi survei berbasis web ini.

\section{Analisis dan Evaluasi Desain Solusi}

\section{A. Analisis Konteks Pengguna}

Pada tahapan ini ditentukan responden yang berperan sebagai evaluator dari aplikasi survei berbasis web. Adapun responden yang dimaksud ditampilkan pada Tabel 4.1 berikut.

TABEL 2

KARAKTERISTIK PENGgUNA

\begin{tabular}{|l|l|}
\hline Pengguna & \multicolumn{1}{|c|}{ Karakteristik } \\
\hline Responden & $\begin{array}{l}\text { Merupakan pengguna layanan yang } \\
\text { diperlukan pendapatnya pada sebuah } \\
\end{array}$ \\
& $\begin{array}{l}\text { survei dan dapat menggunakan } \\
\text { perangkat teknologi. }\end{array}$ \\
\hline
\end{tabular}

\section{B. Analisis Kebutuhan Pengguna}

Berdasarkan hasil wawancara dengan responden penelitian ini ditemukan beberapa kebutuhan tampilan antarmuka aplikasi survei berbasis web ini, diantaranya ialah sebagai berikut:

a. Memiliki fitur kritik dan saran yang dilengkapi dengan bantuan jawaban sehingga pengguna yang merasa kesulitan dengan jawabannya dapat terbantu dengan fitur tersebut.

b. Memiliki tampilan yang sederhana namun tetap informatif sehingga tidak memakan banyak waktu untuk melakukan loading tampilan antarmuka.

c. Tampilan dan fitur dapat digunakan dengan mudah.

d. Alur proses dapat memudahkan pengguna dalam proses pengisian survei dari awal hingga akhir.

\section{Pembuatan Desain Solusi}

Pada tahapan ini dilakukan pembuatan desain solusi berdasarkan hasil analisis kebutuhan pengguna dan design guideliness and standards.

\section{Arsitektur Sistem}

Arsitektur sistem merupakan gambaran mengenai kebutuhan sistem secara spesifik dan terstruktur. Pada Gambar 3 ditampilkan gambaran mengenai arsitektur sistem aplikasi survei berbasis web ini.

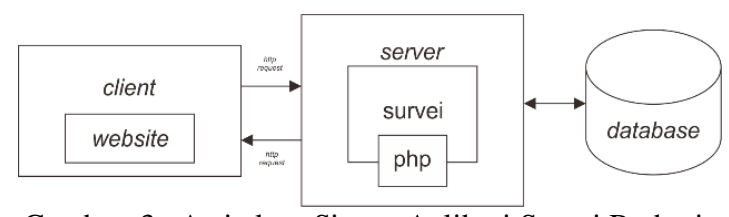

Gambar. 3. Arsitektur Sistem Aplikasi Survei Berbasis Web

Berdasarkan Gambar 3 diatas dapat diketahui bahwa client atau pengguna melakukan akses ke server melalui website dalam web browser. Selanjutnya pengguna melakukan pengisian survei yang terdapat pada website dan kemudian dikirim ke server. Data yang dikirimkan kepada server disimpan dalam database (PHPMyAdmin). Adapun pada server terdapat web server yang berisikan kode program PHP. 


\section{Use Case Diagram}

Use case diagram digunakan untuk menggambarkan aktivitas yang terdapat pada aplikasi. Pada Gambar 4 berikut ditampilkan use case diagram pada aplikasi survei berbasis web.

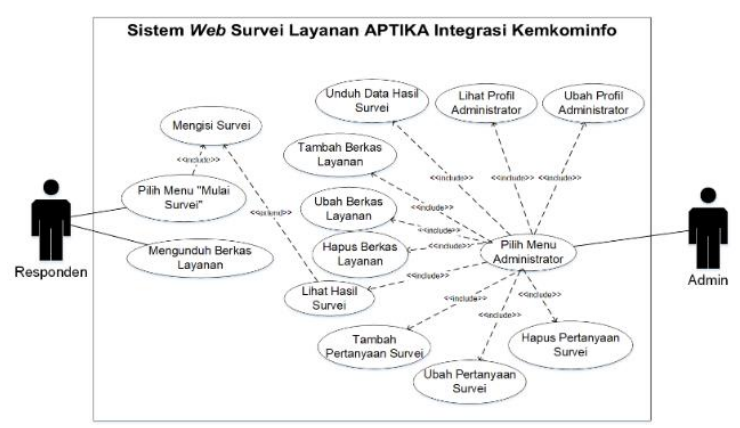

Gambar. 4. Use Case Diagram Aplikasi Survei Berbasis Web

\section{Class Diagram}

Class diagram digunakan untuk menggambarkan hubungan yang terjadi antara kelas-kelas beserta dengan atribut dan operasi pada aplikasi. Pada Gambar 5 berikut ditampilkan class diagram pada aplikasi survei berbasis web.

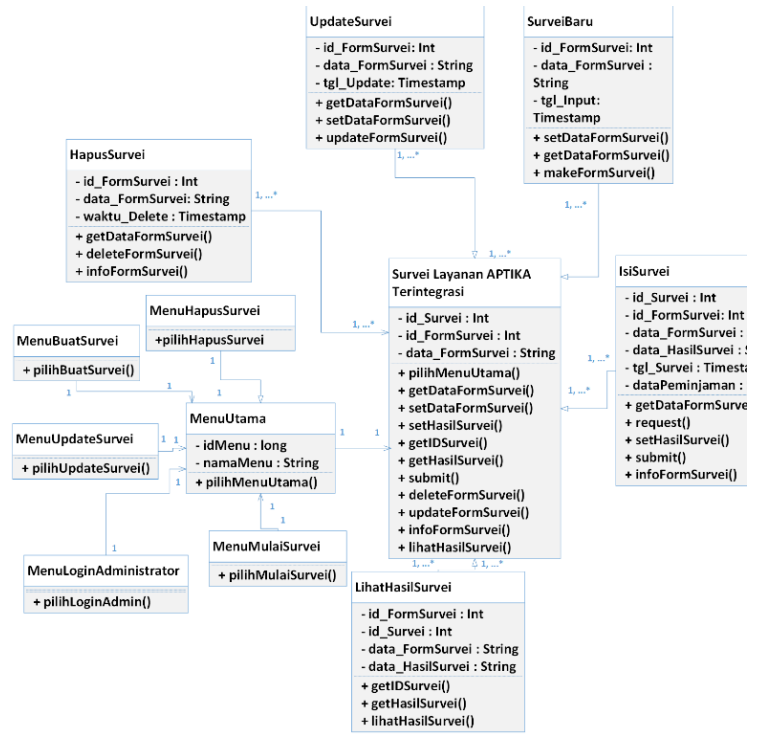

Gambar. 5. Class Diagram Aplikasi Survei Berbasis Web

\section{Perancangan Desain Solusi}

Perancangan dari desain solusi dibuat mengacu pada hasil analisis kebutuhan dan kendala yang dihadapi pengguna dengan mempertimbangkan aturan-aturan yang terdapat pada HSS Guidelines. Pada Gambar 6 berikut ini ditampilkan usulan desain solusi untuk halaman utama aplikasi survei berbasis web.

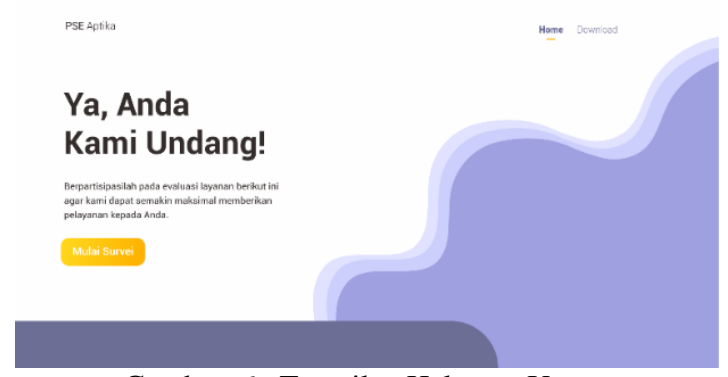

Gambar. 6. Tampilan Halaman Utama

Adapun pada Gambar 7 berikut ditampilkan usulan desain solusi untuk halaman survei.

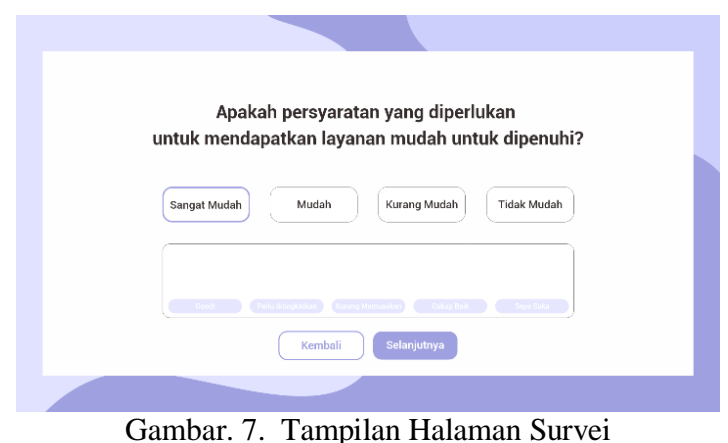

Pada Gambar 8 berikut ditampilkan usulan desain solusi untuk halaman unduh berkas.

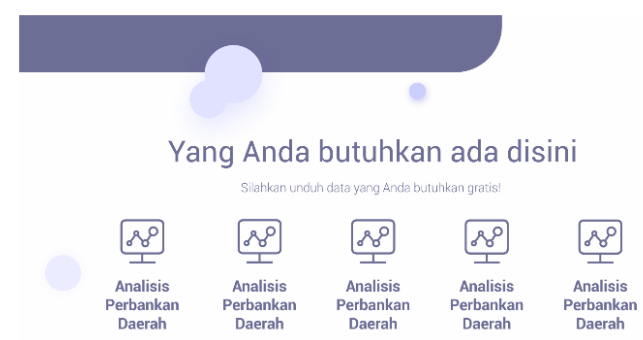

Gambar. 8. Tampilan Halaman Unduh Berkas

\section{Evaluasi Desain Solusi}

Pada tahapan ini evaluasi yang dilakukan berdasar pada tiga aspek usability yakni, efektivitas, efisiensi serta kepuasan pengguna. Pada aspek efektivitas diukur melalui tugas yang diberikan kepada 
responden, tugas yang diberikan dikerjakan oleh responden dengan pengawasan peneliti. Jika responden mampu menyelesaikan tugas maka akan diberi label "berhasil" pada lembar observasi. Namun jika responden tidak berhasil akan diberi label "tidak berhasil".

Pada aspek efisiensi responden akan mengerjakan tugas-tugas tertentu dengan pengawasan peneliti yang akan mengukur waktu yang dibutuhkan oleh responden dalam menyelesaikan tugas-tugas yang disediakan.

Pada aspek kepuasan pengguna, responden diberikan kuesioner untuk dilakukan penilaian oleh responden pada aspek yang dibahas.

\section{Penentuan Tugas}

Adapun tugas yang diberikan kepada responden ditampilkan pada Tabel 3 berikut:

TABEL 3

TUGAS RESPONDEN

\begin{tabular}{|l|l|}
\hline \multicolumn{1}{|c|}{ No. } & \multicolumn{1}{c|}{ Tugas Responden } \\
\hline 1. & Mengisi survei \\
\hline 2. & Melakukan unduh berkas \\
\hline
\end{tabular}

2. Hasil Evaluasi Tampilan Antarmuka pada Aspek Efektivitas

Adapun hasil observasi dari evaluasi pada aspek efektivitas ditampilkan pada tabel 4 berikut:

TABEL 4

Hasil Evaluasi TAMPILAN AsPek EFEKTIVITAS

\begin{tabular}{|l|l|c|}
\hline No. & Tugas Responden & $\begin{array}{c}\text { Tingkat } \\
\text { Keberhasilan }\end{array}$ \\
\hline 1. & Mengisi survei & $100 \%$ \\
\hline 2. & $\begin{array}{l}\text { Melakukan unduh } \\
\text { berkas }\end{array}$ & $100 \%$ \\
\hline
\end{tabular}

3. Hasil Evaluasi Tampilan Antarmuka pada Aspek Efisiensi

Adapun hasil observasi dari evaluasi pada aspek efisiensi ditampilkan pada tabel 5 berikut:

TABEL 5

Hasil Evaluasi TAMPILAN ASPEK EFISIENSI

\begin{tabular}{|l|l|c|}
\hline No. & \multicolumn{1}{|c|}{ Tugas Responden } & $\begin{array}{c}\text { Rata-rata } \\
\text { Waktu } \\
\text { Pengerjaan }\end{array}$ \\
\hline 1. & Mengisi survei & $00: 08: 40$ \\
\hline 2. & Melakukan unduh berkas & $00: 07: 24$ \\
\hline
\end{tabular}

4. Hasil Evaluasi Tampilan Antarmuka pada Aspek Kepuasan Pengguna

Adapun hasil observasi dari evaluasi pada aspek kepuasan pengguna diketahui nilai rata-rata yakni sebesar $85,6 \%$ pengguna merasa puas dengan tampilan aplikasi yang tersedia.

\section{E. Analisis Hasil Evaluasi Desain Solusi \\ 1. Analisis Aspek Efektivitas}

Evaluasi tampilan antarmuka pada aspek efektivitas sebelum dilakukan pengembangan memiliki hasil sebesar $100 \%$ pengguna berhasil melakukan pengisian survei hingga tuntas dan sebesar 100\% pengguna berhasil melakukan unduh berkas. Namun setelah dilakukan pengembangan, diperoleh hasil sebesar $100 \%$ pengguna berhasil melakukan pengisian survei hingga tuntas dan sebesar $100 \%$ pengguna berhasil melakukan unduh berkas, sehingga pada aspek efektivitas tidak ditemui adanya peningkatan yang signifikan.

\section{Analisis Aspek Efisiensi}

Evaluasi tampilan antarmuka pada aspek efisiensi sebelum dilakukan pengembangan memiliki hasil rata-rata waktu pengerjaan selama 32 detik untuk pengguna dapat melakukan pengisian survei pada satu halaman dan selama 10 detik untuk pengguna dapat melakukan unduh berkas. Namun setelah dilakukan pengembangan, diperoleh hasil rata-rata waktu pengerjaan selama 8 detik untuk pengguna dapat melakukan pengisian survei pada satu halaman dan selama 7 detik untuk pengguna dapat melakukan unduh berkas, sehingga terjadi peningkatan yang signifikan pada aspek ini.

\section{Analisis Aspek Kepuasan Pengguna}

Evaluasi tampilan antarmuka pada aspek kepuasan pengguna sebelum dilakukan pengembangan diketahui memiliki nilai ratarata sebesar $79,7 \%$. namun setelah dilakukan pengembangan, diperoleh nilai rata-rata sebesar $85,6 \%$, sehingga pada aspek ini mengalami peningkatan yang signifikan. 


\section{Kesimpulan dan Saran}

Berdasarkan hasil analisis, perancangan dan evaluasi dari aplikasi survei berbasis web menggunakan metode UCD, dapat disimpulkan bahwa analisis konteks dan kebutuhan pengguna, dengan melakukan wawancara terhadap pengguna aplikasi untuk memperoleh data kebutuhan dapat menjadi dasar perancangan pengembangan aplikasi survei berbasis web ini. Adapun hasil analisis tersebut diimplementasikan menjadi bentuk use case diagram dan class diagram. Berdasarkan rancangan tersebut telah dikembangkan prototipe tampilan antarmuka yang dapat dijadikan dasar untuk membangun aplikasi survei berbasis web mengingat telah dilakukannya evaluasi terhadap prototipe yang dirancang dengan nilai rata-rata sebesar $85,6 \%$ pengguna merasa puas dengan tampilan aplikasi yang dirancang. Adapun tabel perbandingan evaluasi tampilan antarmuka terhadap aspek-aspek usability ditampilkan pada Tabel 6 berikut:

TABEL 6

Perbandingan Evaluasi Tampilan AnTARMUKa

\begin{tabular}{|l|c|c|}
\hline \multicolumn{3}{|c|}{ Aktivitas: Mengisi survei } \\
\hline $\begin{array}{l}\text { Aspek } \\
\text { Usability }\end{array}$ & $\begin{array}{l}\text { Hasil Sebelum } \\
\text { Pengembangan }\end{array}$ & $\begin{array}{l}\text { Hasil Setelah } \\
\text { Pengembangan }\end{array}$ \\
\hline Efektivitas & $100 \%$ & $100 \%$ \\
\hline Efisiensi & $00: 32: 42$ & $00: 08: 40$ \\
\hline \multicolumn{3}{|c|}{ Aktivitas: Melakukan unduh berkas } \\
\hline $\begin{array}{l}\text { Aspek } \\
\text { Usability }\end{array}$ & $\begin{array}{l}\text { Hasil Sebelum } \\
\text { Pengembangan }\end{array}$ & $\begin{array}{l}\text { Hasil Setelah } \\
\text { Pengembangan }\end{array}$ \\
\hline Efektivitas & $100 \%$ & $100 \%$ \\
\hline Efisiensi & $00: 10: 32$ & $00: 07: 24$ \\
\hline \multicolumn{3}{|c|}{} \\
\hline $\begin{array}{l}\text { Aspek } \\
\text { Usability }\end{array}$ & Hasil Sebelum & $\begin{array}{l}\text { Hasil Setelah } \\
\text { Pengembangan } \\
\text { Kepuasan } \\
\text { Pengguna }\end{array}$ \\
\hline
\end{tabular}

Saran yang dapat diberikan untuk penelitian selanjutnya ialah hasil analisis, perancangan dan evaluasi aplikasi survei berbasis web ini dapat dilanjutkan ke tahap pembangunan. Selain itu aplikasi ini juga dapat diintegrasikan dengan fitur yang mendukung proses kegiatan survei baik perusahaan maupun instansi yang membutuhkan proses evaluasi tertentu.

\section{Daftar Pustaka}

Febriana, F. (2017, Desember 3). User Centered Design. Diambil kembali dari Medium: https://medium.com/codelabsunikom/user-centered-designee25536850b7

Fodor, P. (2017, Agustus 30). Why 7 Seconds Could Make or Break Your Mobile App. Diambil kembali dari Aso Stack: https://asostack.com/why-7-secondscould-make-or-break-your-mobileapp-f41000fb2a17

ISO 9241-210. (2010). Ergonomics of human system interaction In: HumanCentered Design for Interactive Systems. Switzerland: International Organization for Standarization.

ISO DIS 9241-11. (2015). Ergonomics of Human-System Interaction - Part 11: Usability: Definitions and Concepts. Switzerland: International Organization for Standarization.

ISO, 9.-1. (2018). Ergonomics of HumanSystem Interaction. Switzerland: International Organization for Standarization.

Mastery, U. (2019, Agustus 17). UX Techniques. Diambil kembali dari UX Mastery: https://uxmastery.com/resources/tech niques/

Morissan. (2014). Metode Penelitian Survei. Jakarta: Kencana.

Nielsen, J. (2012). Usability 101: Introduction to Usability. Diambil kembali dari nngroup:

https://www.nngroup.com/articles/us ability-101-introduction-to-usability/

Rendiansah, M., Az-Zahra, H., \& Saputra, M. C. (2017). Pengembangan User Interface Aplikasi Guide Me! Berbasis Web dengan Pendekatan Human-Centered Design. Jurnal Pengembangan Teknologi Informasi 
dan Ilmu Komputer Vol. 1 No. 11, Universitas Brawijaya, Malang.

Rouse, M. (2019, Januari 27). Web Application (Web App). Diambil kembali dari TechTarget Magazine: https://searchsoftwarequality.techtarg et.com/definition/Web-applicationWeb-app

Saputri, I. S., Fadhli, M., \& Surya, I. (2017). Penerapan Metode UCD (User Centered Design) pada E-Commerce Putri Intan Shop Berbasis Web. Jurnal Nasional Teknologi dan Sistem Informasi Vol 3 No. 02, 269-278.

Sripathi, V., \& Sandru, V. (2013). Effective Usability Testing-Knowledge of User Centered Design is a Key Requirement. International Journal of Emerging Technology and Advanced Engineering, 3(1), 627-635. 